\title{
Self-assembly of Multi-domain Peptides: Balancing Molecular Frustration Controls Conformation and Nanostructure
}

He Dong, Sergey E. Paramonov, Lorenzo Aulisa, Erica L. Bakota and Jeffrey D. Hartgerink ${ }^{\star}$

Departments of Chemistry and Bioengineering, Rice University, 6100 Main Street, Houston, TX 77005.

jdh@rice.edu

\section{Supporting Information}

Peptide Synthesis and Purification

The syntheses of the peptides were carried out on an Advanced Chem Tech Apex 396 peptide synthesizer using general procedures for Fmoc solid phase chemistry with HBTU, HoBt and DIEA as coupling reagents based on a $0.15 \mathrm{mmol}$ scale. After completion of the peptide sequence assembly, the N-termini of the peptides were acetylated in the presence of $7.5 \mathrm{mmol}$ of acetic anhydride and $0.9 \mathrm{mmol}$ of DIEA in DCM and then cleaved and deprotected with a mixture of TFA / triisopropanolsilane / water (18:1:1 by volume) for 3 hours. After rotary evaporation, the residual TFA solution was triturated with cold diethyl ether and dried under vacuum for 24 hours before further purification.

Purification was done on a Varian PrepStar220 HPLC using a preparative reverse phase C-18 column with a linear water/acetonitrile gradient (each containing $0.05 \%$ TFA) at a flow rate of $14 \mathrm{ml} / \mathrm{min}$. The UV absorption of the eluents was monitored at 230nm. Supplementary Figure SI-9 shows crude HPLC for the peptides. The single pure peak was collected and used for all subsequent analysis. Supplementary Figure SI-10 shows the pure fraction after reinjection for peptides $\mathrm{K}_{2}(\mathrm{QL})_{2} \mathrm{~K}_{2}$ and $\mathrm{K}_{2}(\mathrm{QL})_{3} \mathrm{~K}_{2}$ since their crude synthesis was less clean. MALDI-TOF mass spectrometry was used to characterize the mass of the final products. $\mathrm{K}_{2}(\mathrm{QL})_{2} \mathrm{~K}_{2}$, expected mass $[\mathrm{M}+\mathrm{H}]^{+}: 1054.7$ Observed mass: $1054.6 . \mathrm{K}_{2}(\mathrm{QL})_{3} \mathrm{~K}_{2}$, expected mass $[\mathrm{M}+\mathrm{H}]^{+}$: 1295.8 Observed mass: 1295.8. $\mathrm{K}_{2}(\mathrm{QL})_{4} \mathrm{~K}_{2}$, expected mass $[\mathrm{M}+\mathrm{H}]^{+}$: 1537.0 Observed mass: 1537.9. $\mathrm{K}_{2}(\mathrm{QL})_{5} \mathrm{~K}_{2}$, expected mass $[\mathrm{M}+\mathrm{H}]^{+}:$1778.1 Observed mass: 1778.2. $\mathrm{K}_{2}(\mathrm{QL})_{6} \mathrm{~K}_{2}$, expected mass 
$[\mathrm{M}+\mathrm{H}]^{+}:$2019.3 Observed mass: 2019.4. $\mathrm{K}_{3}(\mathrm{QL})_{6} \mathrm{~K}_{3}$, expected mass $[\mathrm{M}+\mathrm{H}]^{+}: 2275.5$ Observed mass: 2275.6. $\mathrm{K}_{4}(\mathrm{QL})_{6} \mathrm{~K}_{4}$, expected mass $[\mathrm{M}+\mathrm{Na}]^{+}$: 2531.7 Observed mass: 2531.7. $\mathrm{K}_{1}(\mathrm{QL})_{6} \mathrm{~K}_{1}$ was found to be insoluble in the $\mathrm{pH}$ range of 2-12 in water. The aggregation was broken up with the addition of $50 \%$ trifluoroacetic acid, $40 \%$ acetonitrile and $10 \%$ water. The sample then underwent 100 fold dilution in $30 \%$ water and $70 \%$ acetonnitrile to give a final concentration of $1 \mathrm{ug} / \mathrm{ml}$ for mass acquisition. Expected mass $\left[\mathrm{M}+\mathrm{Na}^{+}\right]$: 1885.1. Observed mass $\left[\mathrm{M}+\mathrm{Na}^{+}\right]$: 1885.2.

Samples prepared at a final concentration of $1 \mathrm{wt} \%$ peptide and $10 \mathrm{mM}$ Tris buffer at a $\mathrm{pH}$ of 7.4 by diluting a stock solution at 2 wt $\%$ peptide in distilled water with Tris buffer. For some experiments, $\mathrm{NaOH}$ was used to adjust the $\mathrm{pH}$ to 12 to induce gelation (except $\mathrm{K}_{2}(\mathrm{QL})_{2} \mathrm{~K}_{2}$ which remains soluble at this $\mathrm{pH}) .1 \%$ by weight in Tris buffer corresponds to $10 \mathrm{mg} / \mathrm{ml}$. For $\mathrm{K}_{2}(\mathrm{QL})_{3} \mathrm{~K}_{2}=9.5 \mathrm{mM}, \mathrm{K}_{2}(\mathrm{QL})_{4} \mathrm{~K}_{2}=7.7 \mathrm{mM}, \mathrm{K}_{2}(\mathrm{QL})_{4} \mathrm{~K}_{2}=6.5 \mathrm{mM}, \mathrm{K}_{2}(\mathrm{QL})_{5} \mathrm{~K}_{2}=5.6 \mathrm{mM}$, $\mathrm{K}_{2}(\mathrm{QL})_{6} \mathrm{~K}_{2}=5.0 \mathrm{mM}, \mathrm{K}(\mathrm{QL})_{6} \mathrm{~K}=5.7, \mathrm{~K}_{3}(\mathrm{QL})_{6} \mathrm{~K}_{3}=4.4, \mathrm{~K}_{4}(\mathrm{QL})_{6} \mathrm{~K}_{4}=3.9 \mathrm{mM}$.

\section{Circular Dichroism Measurement}

CD spectra were recorded on a Jasco-J810 spectropolarimeter using quartz cells with the path length of $0.01 \mathrm{~mm}$. Spectra were collected at room temperature from $250 \mathrm{~nm}$ to $180 \mathrm{~nm}$ with a $0.2 \mathrm{~nm}$ interval at a rate of $50 \mathrm{~nm} / \mathrm{min}$. Millidegrees of rotation were converted to mean residual ellipticity.

\section{FTIR measurement}

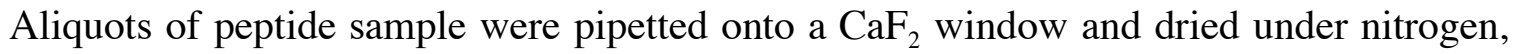
or gold mirror and spin coated on the surface to form a thin layer of peptide nanofibers. Grazing angle FT-IR spectra were recorded with a 80Spec specular reflectance accessory (PIKE 
Technologies). Both samples were then examined using a Jasco FTIR 660plus. Collected spectra were linear baseline corrected and subsequently deconvoluted by fitting with a mixed Gaussian / Lorentzian by a least squares method.

By changing the orientation of the incoming IR beam with respect to the peptide nanofibers, one can achieve enhancement / attenuation of one mode over the other, which allows us to discern the orientation of peptide backbone and the intermolecular hydrogen bonding with respect to the nanofiber network (J.Am. Chem. Soc 2006, 128, 7291). In the case of the grazing angle IR experiment, where the IR incoming beam is nearly parallel to the substrate surface the amide I (primarily a stretching of $\mathrm{C}=\mathrm{O}$ ) and $\mathrm{NH}$ stretching modes were attenuated relative to the amide II mode (in plane $\mathrm{NH}$ bending and $\mathrm{CN}$ stretching). In contrast, when the IR beam is perpendicular to the fibers as is the case when they are deposited on the $\mathrm{CaF}_{2}$ window, the amide I band and NH stretching modes are enhanced relative to the amide II. This indicates that the hydrogen bonding is parallel to the nanofiber axis with peptide backbone running perpendicular to the fiber axis, which is described as a "cross-beta sheet" conformation. Also, the enhancement of amide I peak at $1692 \mathrm{~cm}^{-1}$ in grazing angle IR versus transmission IR clearly demonstrates the anti-parallel orientation of beta sheets.

\section{Vitreous Ice Cryo-TEM}

Vitreous ice cryo-TEM samples were preapared according to the general procedure published by Milligan et. al, ${ }^{1}$ (J. Cell Biol. 1987, 105, 29-39) using a controlled environment vitrification system (Vitrobot, FEI). 6 (for samples at $\mathrm{pH}$ 7.4) or $2 \mu \mathrm{l}$ (for samples at $\mathrm{pH}$ 12) of sample were pipetted onto a holey carbon grid (Quantifoil R1.2/1.3) and gently blotted for $1 \mathrm{sec}$ resulting in a thin film on the surface of a carbon grid. The sample then was plunged into liquid ethane to vitrify the remaining water. The sample obtained was transferred on the cryoholder (Gatan 
$626 \mathrm{DH})$ using its workstation and observed on the JEM 2010 microscope at $-176{ }^{\circ} \mathrm{C}$, equipped with CCD camera (Gatan 2x2K).

\section{Dynamic Light Scattering}

Size distribution analysis was carried out using a Brookhaven ZetaPALS dynamic light scattering (DLS) instrument with a BI-9000AT digital autocorrelator at $656 \mathrm{~nm}$ wavelength. All measurements were done at $90^{\circ}$ scattering angle and at $25^{\circ} \mathrm{C}$ controlled temperature using 50$2000 \mu \mathrm{L}$ polystyrene cuvettes provided by Eppendorf. The data were collected over a time of 10 minutes using 9KDLSW software and processed using the non-negatively constrained least square (NNLS) or Continuous Regularization (CONTIN) algorithm. For each analysis the peptide concentration was kept constant at $1 \% \mathrm{w} / \mathrm{w}$ in $10 \mathrm{mM}$ Tris buffer, $\mathrm{pH}$ 7.4.

Using the following equation to calculate the hydrodynamic radius of a rod:

Where $\sigma=\ln (\mathrm{L} / \mathrm{r})$

$$
R_{h}=\frac{L}{2 \sigma-0.19-\frac{8.24}{\sigma}+\frac{12}{\sigma^{2}}}
$$

$\mathrm{L}=$ length of the rod

$\mathrm{r}=$ radius of the rod

(J. Chem. Phys. 1960, 32 1626-1631; J. Phys. Chem. 1978, 82 1375-1378; and more recently Macromol. Chem. Phys. 2003, 204, 2258-2264)

Plugging in the value derived from cryo-TEM for $\mathrm{L}$ of $120 \mathrm{~nm}$ and a radius of $3 \mathrm{~nm}$ from modeling we find that $R_{h}$ is $20 \mathrm{~nm}$ giving a diameter of $40 \mathrm{~nm}$. This matches well with the DLS data which shows diameters ranging from 30 to $45 \mathrm{~nm}$.

\section{Atomic Force Microscopy}

$10 \mu \mathrm{L}$ of a $0.01 \mathrm{wt} \%$ solution of $\mathrm{K}_{2}(\mathrm{QL})_{6} \mathrm{~K}_{2}$ in Tris buffer at $\mathrm{pH}=7.4$ were dropped onto freshly cleaved mica while spinning on a Headway Research, Inc. Photo-resist spinner. The 
sample was spun for 10 minutes and then rinsed with deionized water for 1-2 seconds. The sample was spun for an additional 10 minutes and then placed in a desiccator for 24 hours prior to imaging. AFM images were collected in air, at ambient temperature, on a Digital Instruments Nanoscope IIIa in tapping mode. 


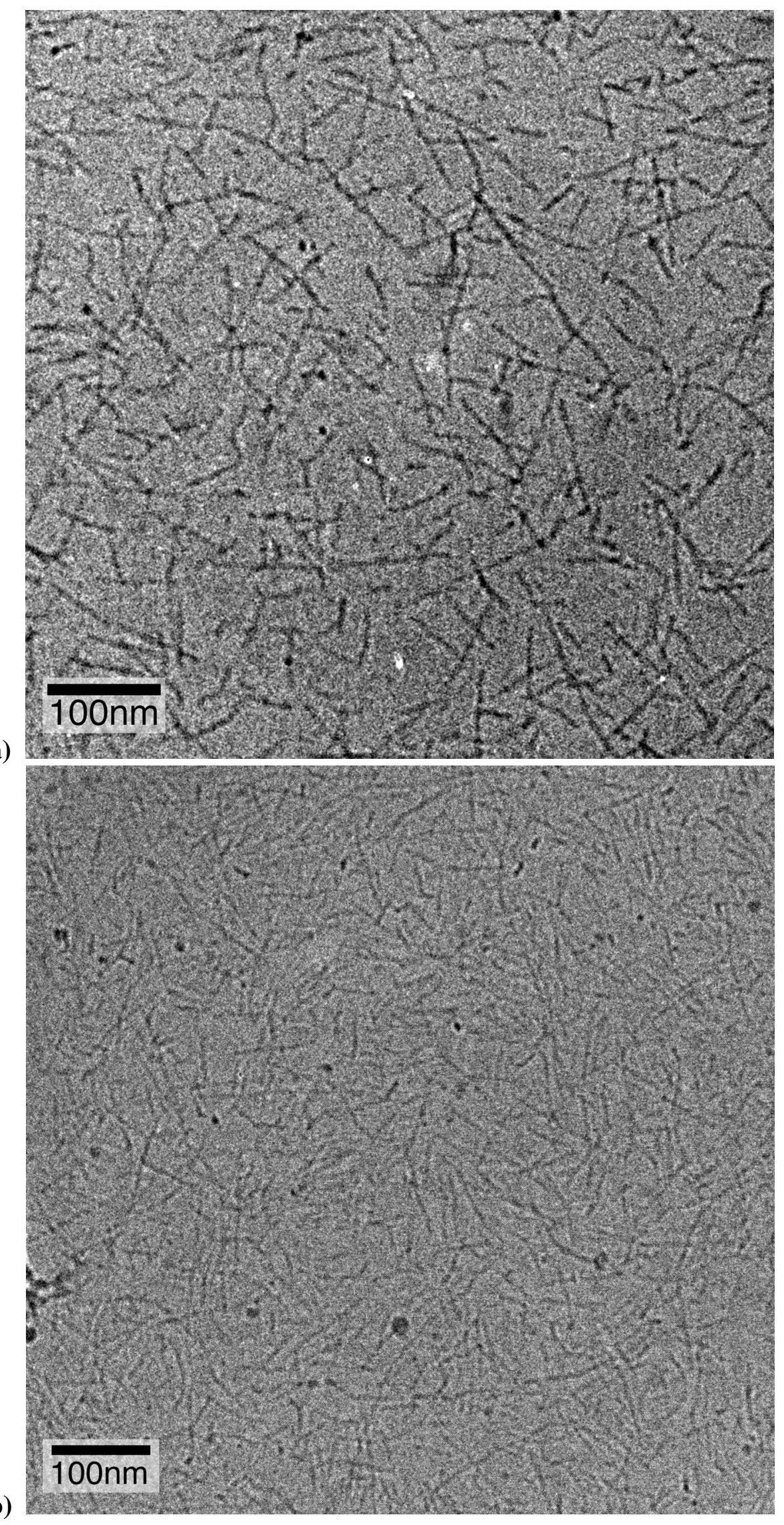




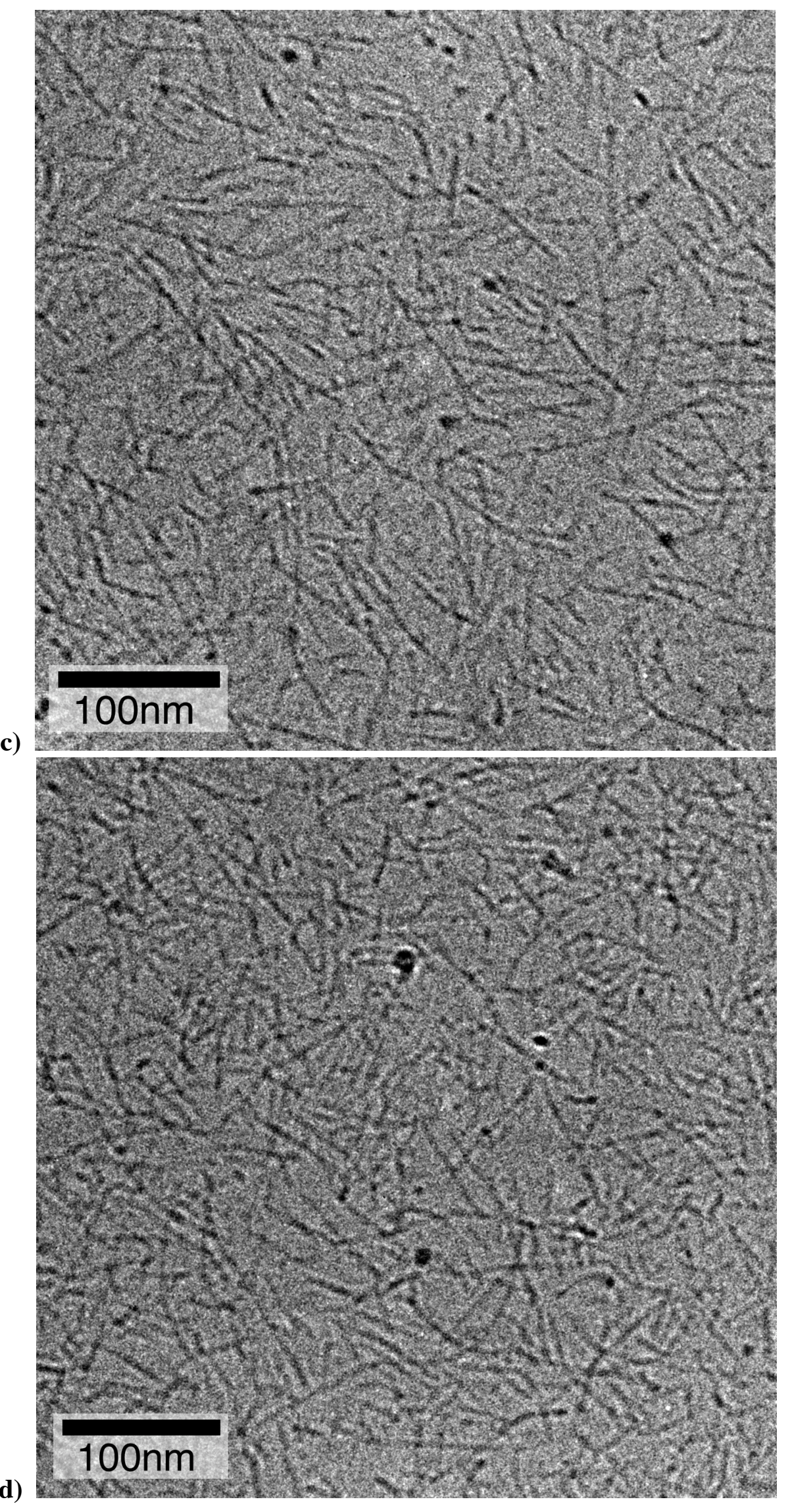




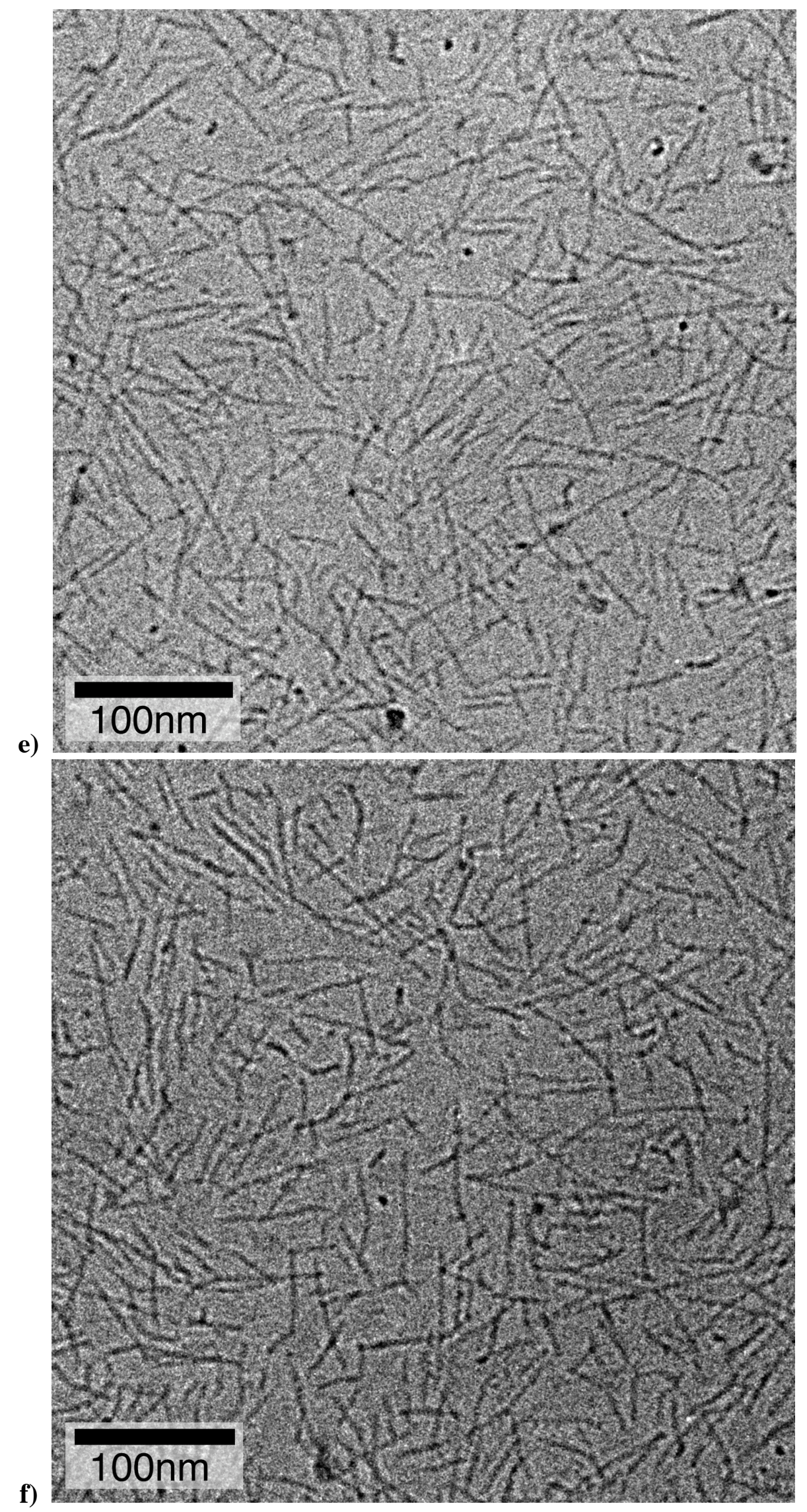




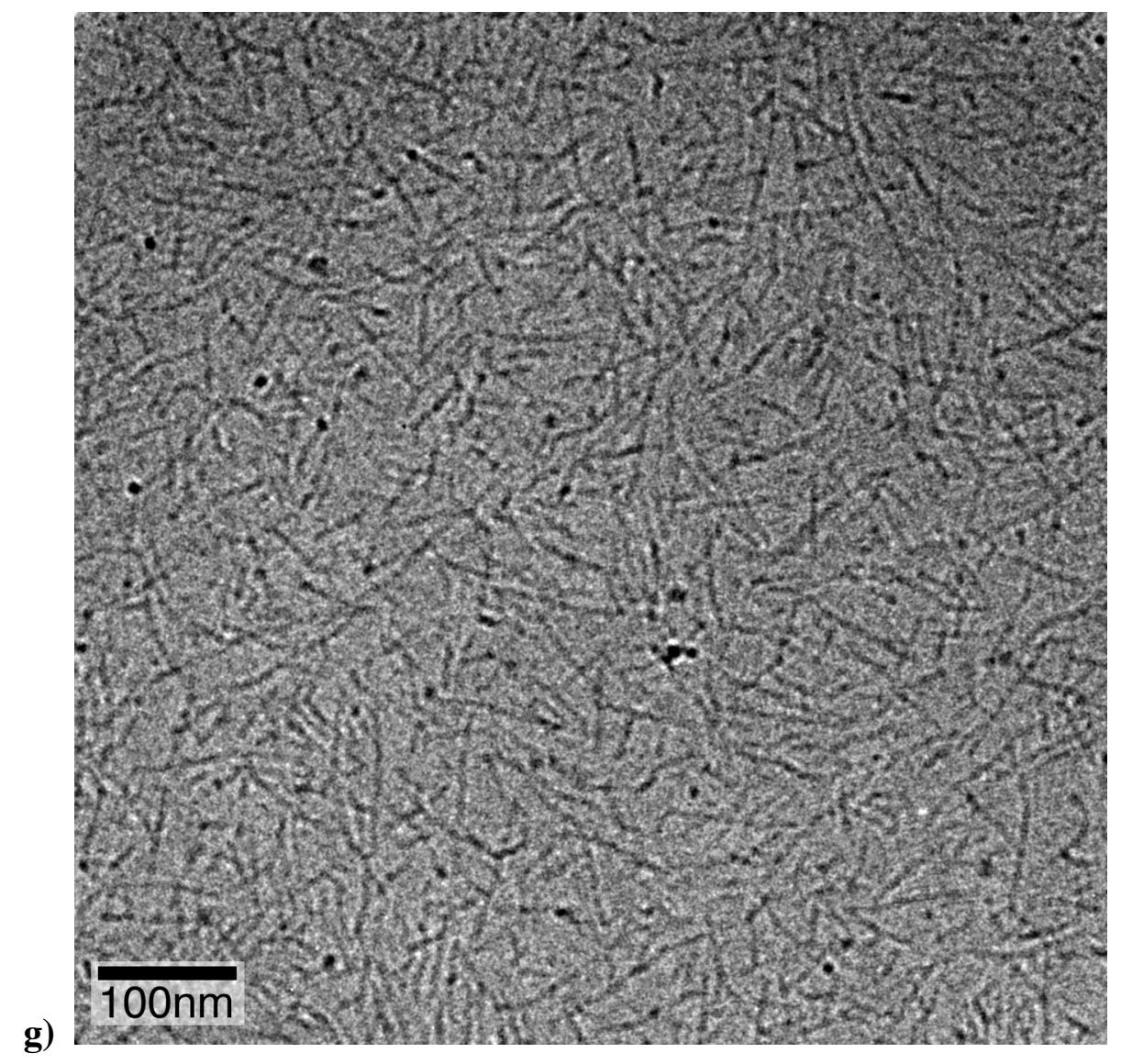

Supplemental Figure S1. Cryo-TEM images of $\mathrm{K}_{2}(\mathrm{QL})_{6} \mathrm{~K}_{2}$ prepared at a concentration of $1 \%$ by weight $(5 \mathrm{mM})$ in $10 \mathrm{mM}$ Tris at $\mathrm{pH} 7.4$. 

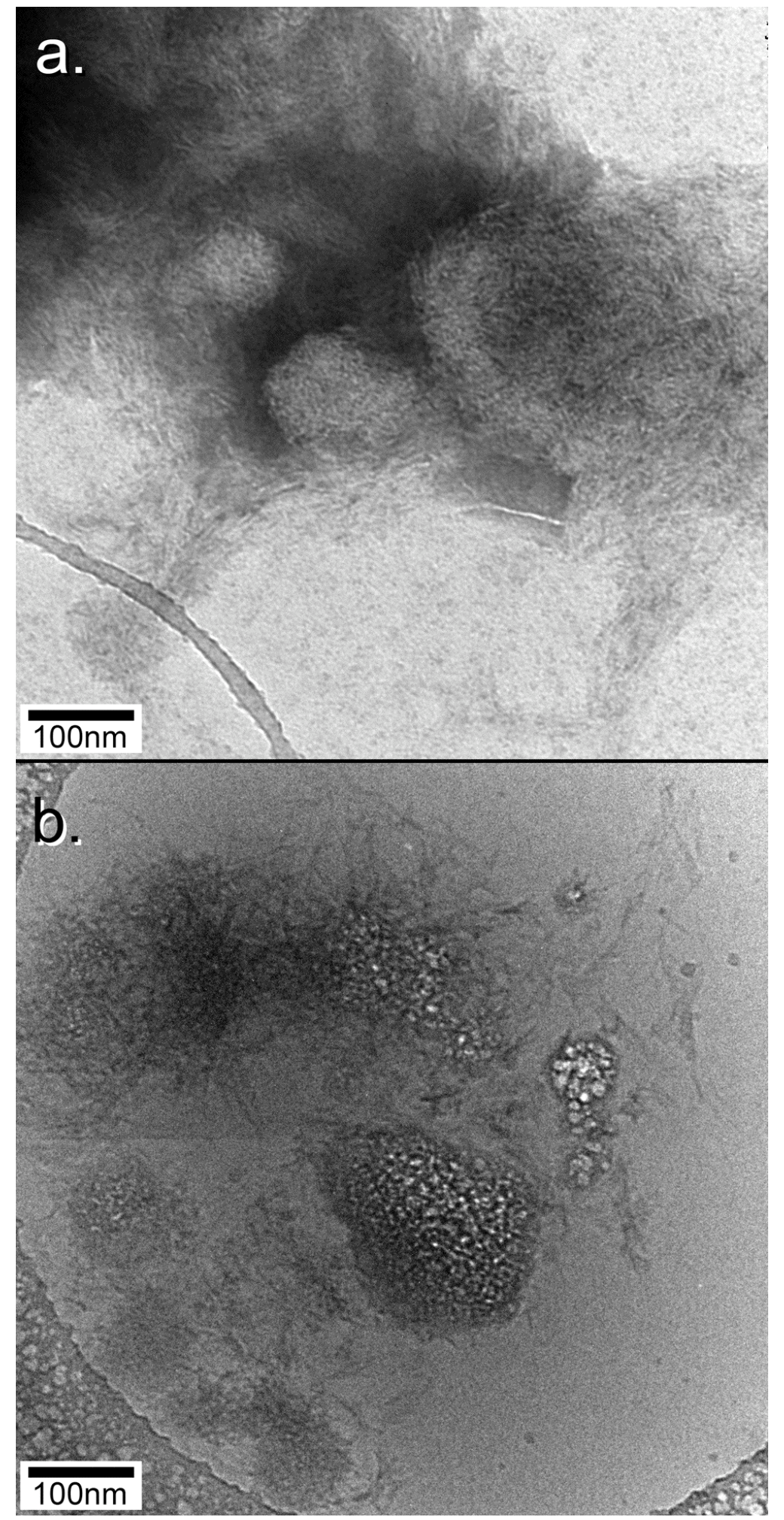

Supplemental Figure SI-2. (QL) $)_{6}$ as examined by (a) negative stain (using phosphotungstic acid, PTA) TEM and (b) vitreous ice cryo-TEM. The insoluble peptide was dispersed via sonication and was able to be visualized as dense aggregations of fibers with diameters similar to those seen in $\mathrm{K}_{2}(\mathrm{QL})_{6} \mathrm{~K}_{2}$. 


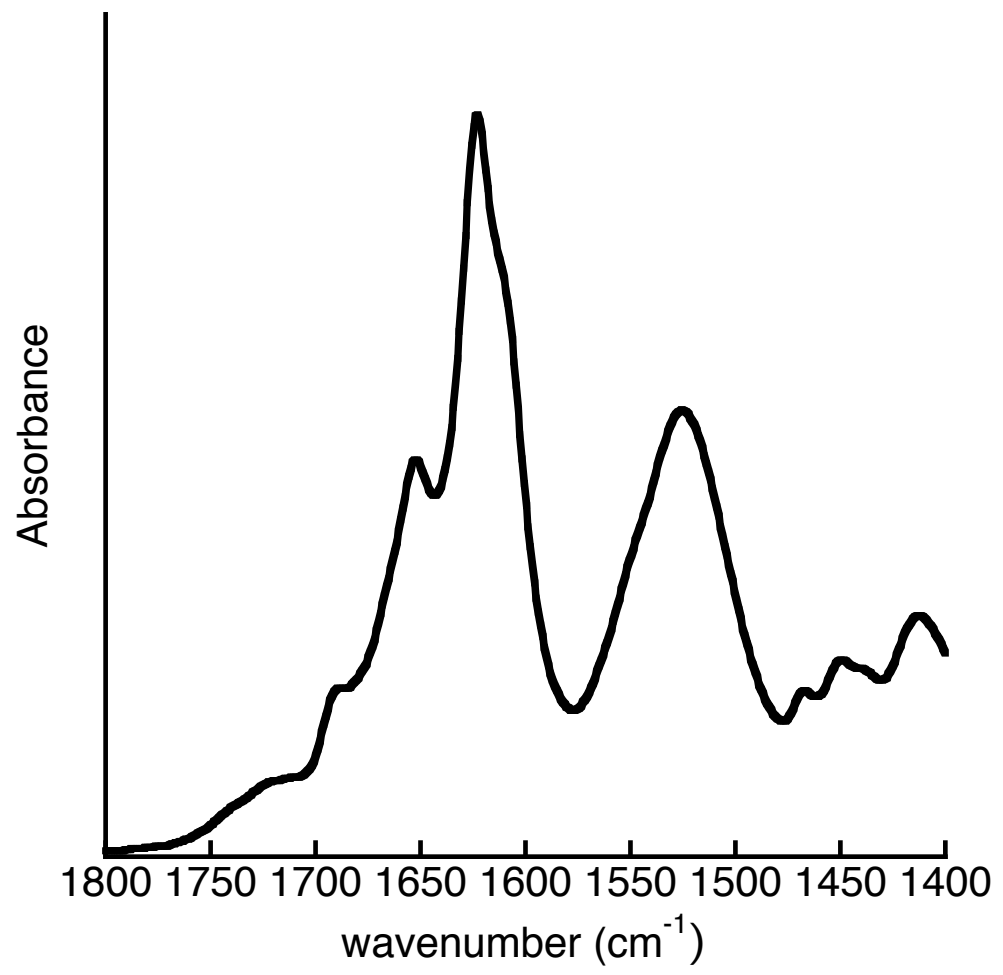

Supplemental Figure SI-3. $(\mathrm{QL})_{6}$ as examined by ATR FT-IR. Prominent amide I band at $1623 \mathrm{~cm}^{-1}$ and minor peak at $1690 \mathrm{~cm}^{-1}$ indicates the presence of anti-parallel $\beta$-sheets. 


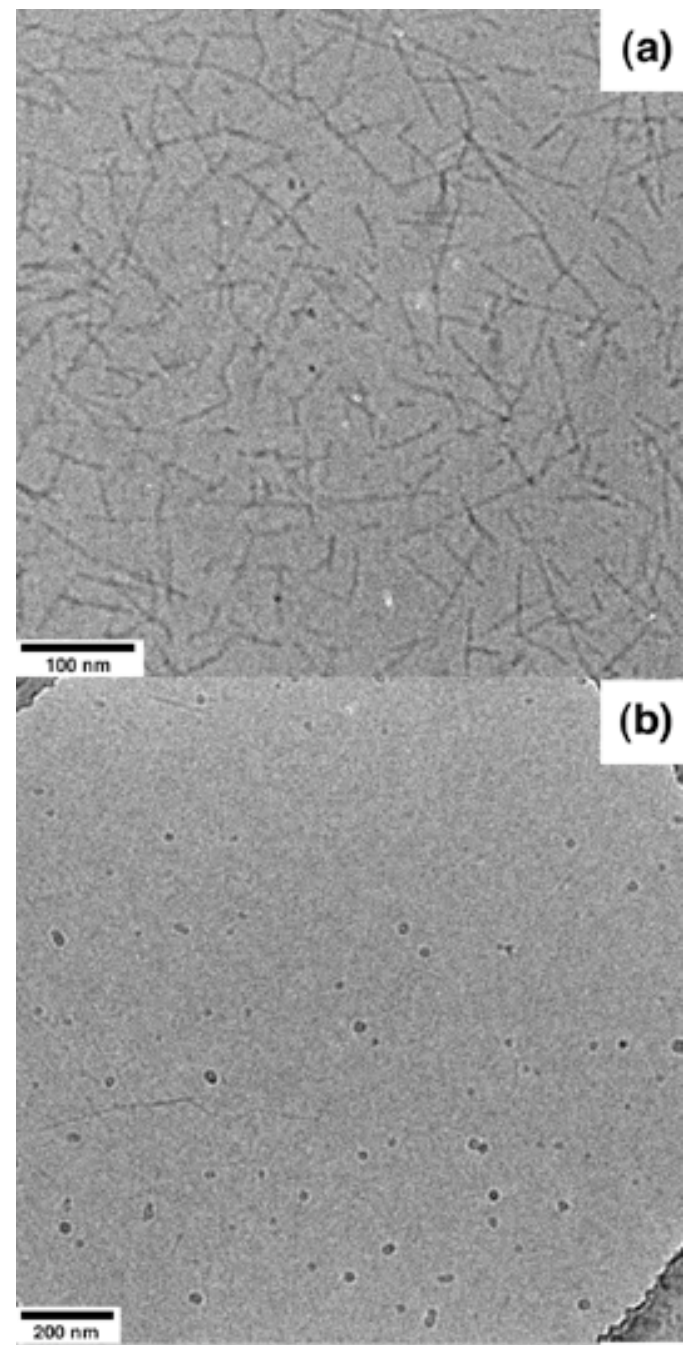

(c)

$\overline{100 \mathrm{~nm}}$

Supplemental Figure SI-4. Cryo-TEM images of (a) $\mathrm{K}_{2}(\mathrm{QL})_{6} \mathrm{~K}_{2}$. (b) $\mathrm{K}_{3}(\mathrm{QL})_{6} \mathrm{~K}_{3}\left(\right.$ c) $\mathrm{K}_{4}(\mathrm{QL})_{6} \mathrm{~K}_{4}$ at $1 \mathrm{wt}$ $\%, 10 \mathrm{mM}$ Tris, $\mathrm{pH} 7.4$. 


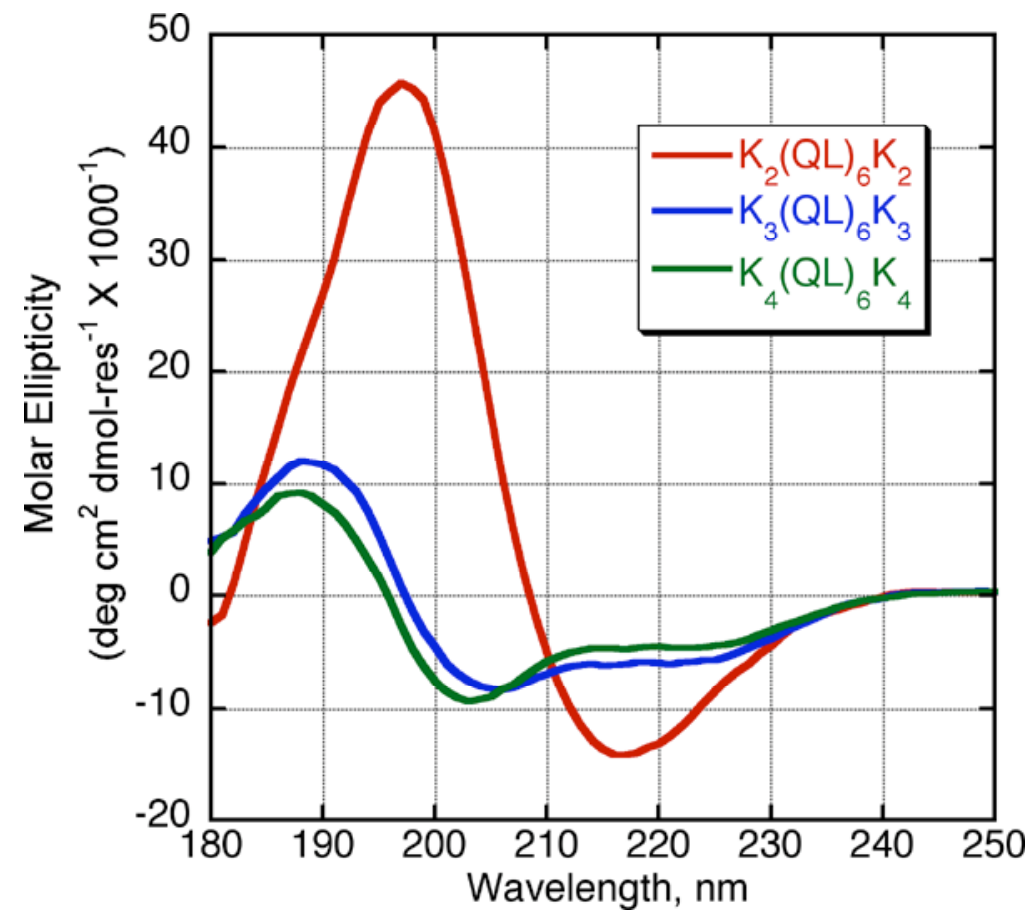

Supplemental Figure SI-5. CD spectra for (QL) $)_{6}$ series of

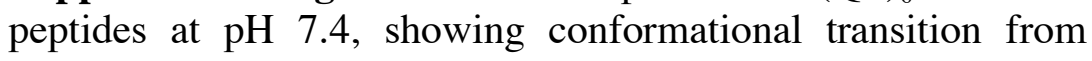
weak $\alpha$ helix to $\beta$ sheet. It is well known that poly-lysine shows similar trend of structural transition between random coil, $\alpha$ helix and $\beta$-sheet (Biophys. Res. Commun. 1966, 23, 163-169). 


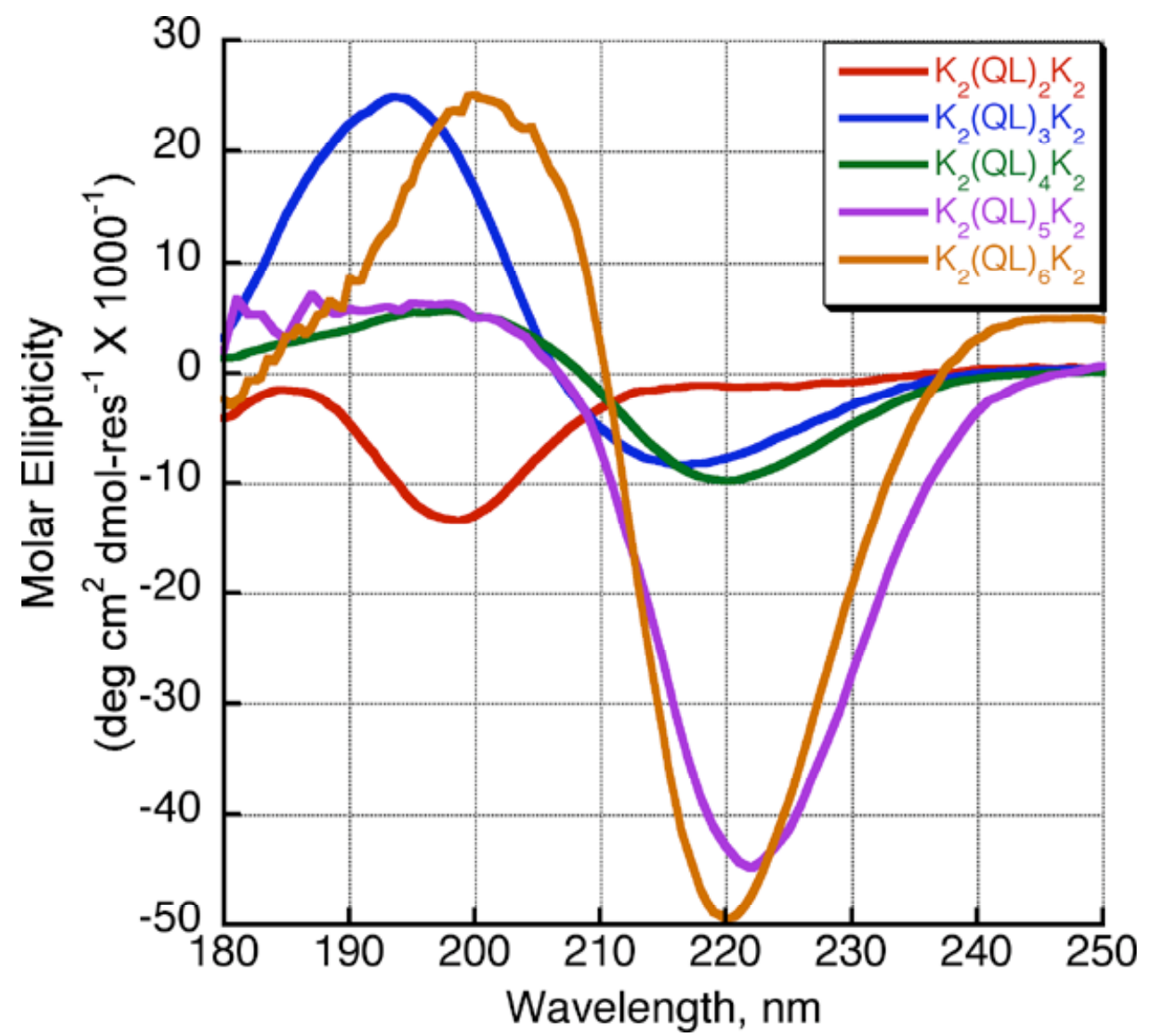

Supplemental Figure SI-6. CD spectra of $\mathrm{K}_{2}(\mathrm{QL})_{\mathrm{m}} \mathrm{K}_{2}(\mathrm{~m}=2-6)$ at $\mathrm{pH} 12$. All samples with the exception of $\mathrm{K}_{2}(\mathrm{QL})_{2} \mathrm{~K}_{2}$ display significant beta-sheet characteristics as indicated by the negative peak near $220 \mathrm{~nm}$. 

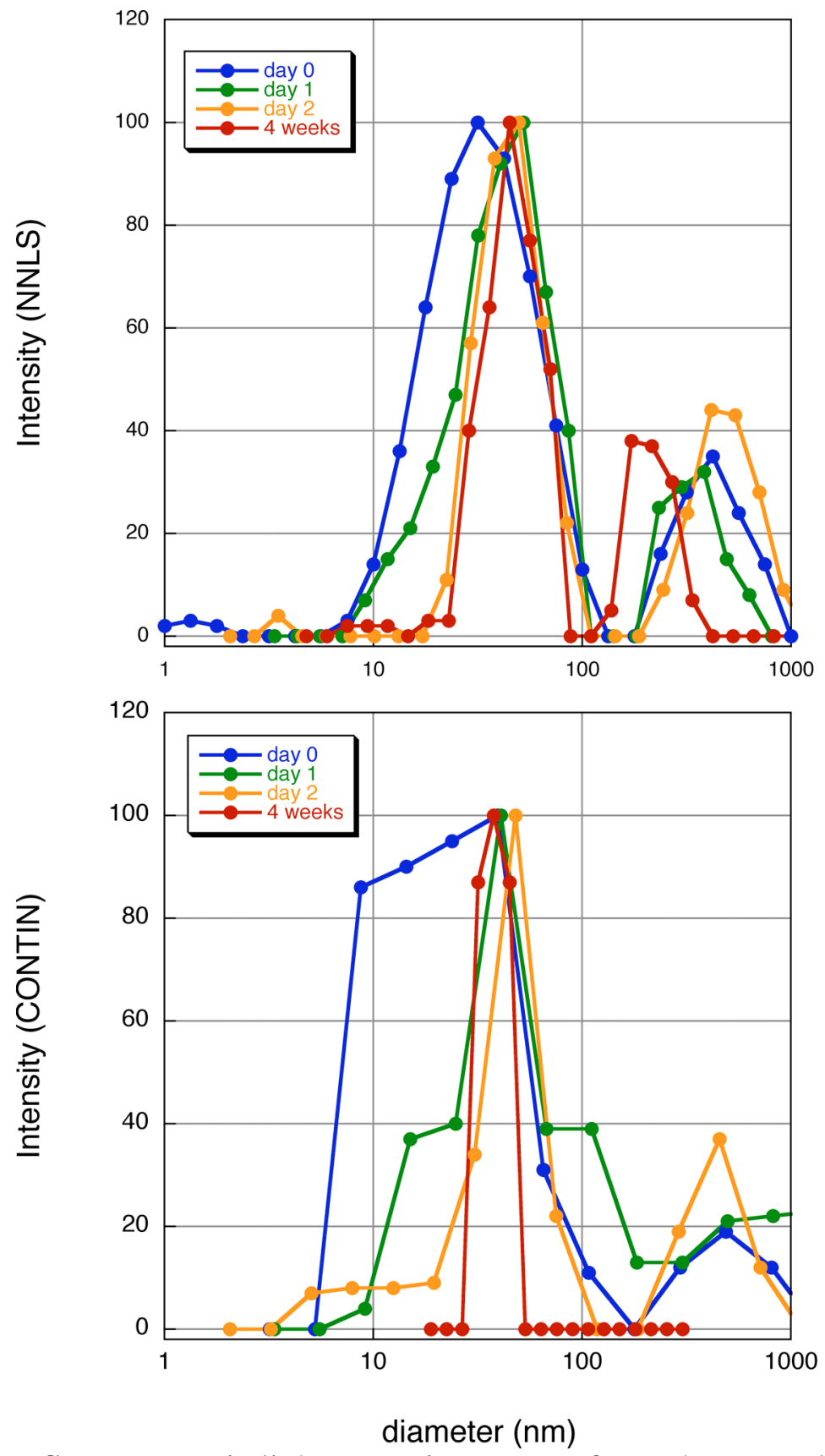

Supplemental Figure SI-7. Dynamic light scattering was performed on samples of $\mathrm{K}_{2}(\mathrm{QL})_{6} \mathrm{~K}_{2}$ prepared at a concentration of $1 \%$ by weight in $10 \mathrm{mM}$ Tris at $\mathrm{pH}$ 7.4. Samples were examined within a few hours of preparation and again after approximately 1,2 and 4 weeks. Two populations were observed. The smaller of the populations consistently had maximum lengths near $100 \mathrm{~nm}$ while the minimum length moved from $10 \mathrm{~nm}$ to $25 \mathrm{~nm}$ making the overall polydispersity of the population shrink over time while average length increased from about 30 to $45 \mathrm{~nm}$. Size measurement by DLS can not be directly compared to that in TEM because DLS assumes a spherical particle geometry; DLS significantly under estimates fiber length. A second population was observed centered near $350 \mathrm{~nm}$ moving to $150 \mathrm{~nm}$ at 28 days. The lower intensity of this population coupled with the Raleigh effect which leads to the higher intensity per larger particle suggests that this population is a minor component of the sample, perhaps due to small bundles or aggregates of fibers. top: NNLS fit. bottom: CONTIN fit. 


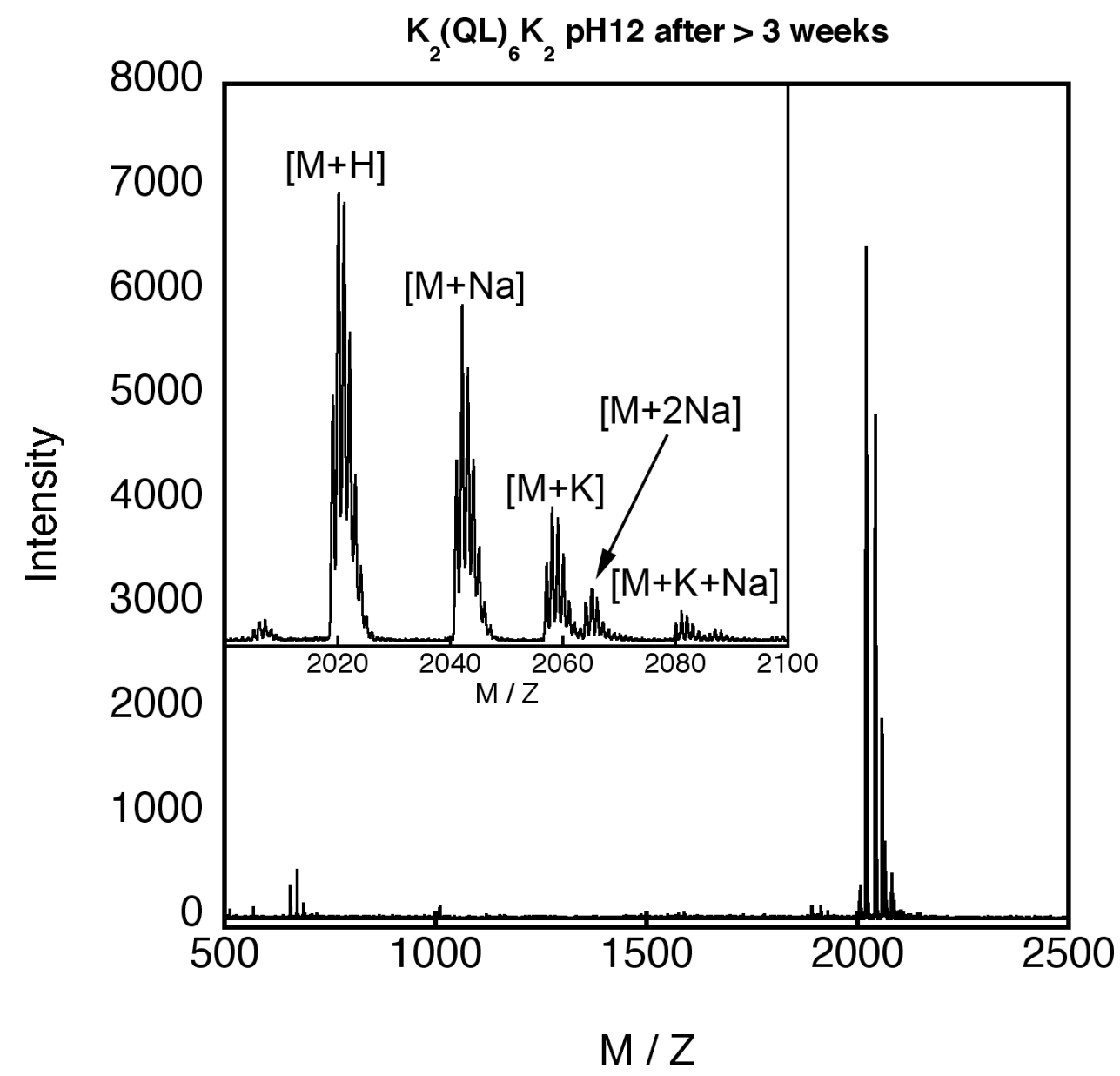

Supplemental Figure SI-8. $\mathrm{K}_{2}(\mathrm{QL})_{6} \mathrm{~K}_{2}$ was incubated at $\mathrm{pH} 12$ in excess of 24 hours at $\mathrm{pH} 12$ to assess the possibility of backbone or glutamine side chain hydrolysis. MALDI-TOF MS indicates that the structure is not altered in the time examined. Gln --> Glu hydrolysis results in a net increase in mass of 1 Dalton and was not observed. 

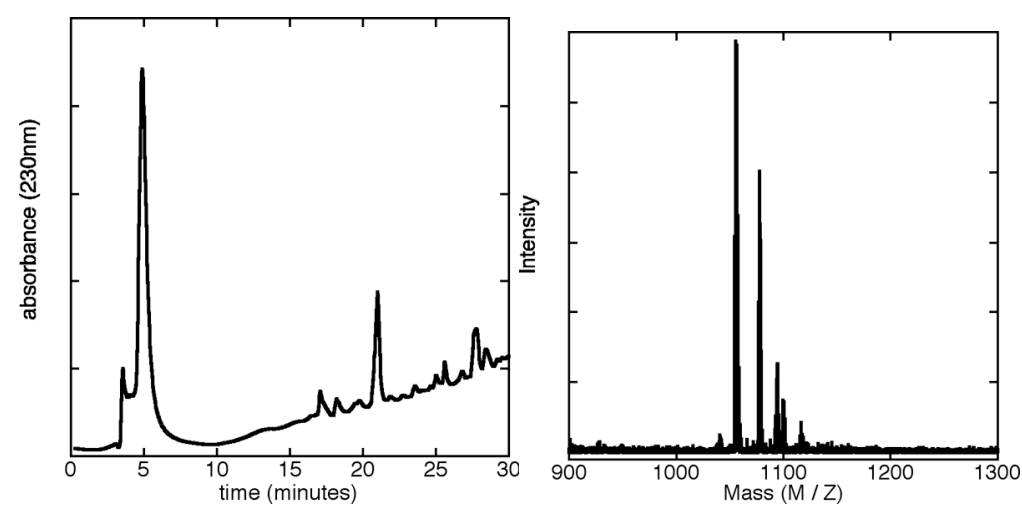

Supplemental Figure SI-9a. HPLC and MS of $\mathrm{K}_{2}(\mathrm{QL})_{2} \mathrm{~K}_{2}$. See $\mathbf{S I 1 0}$ for reinjection.

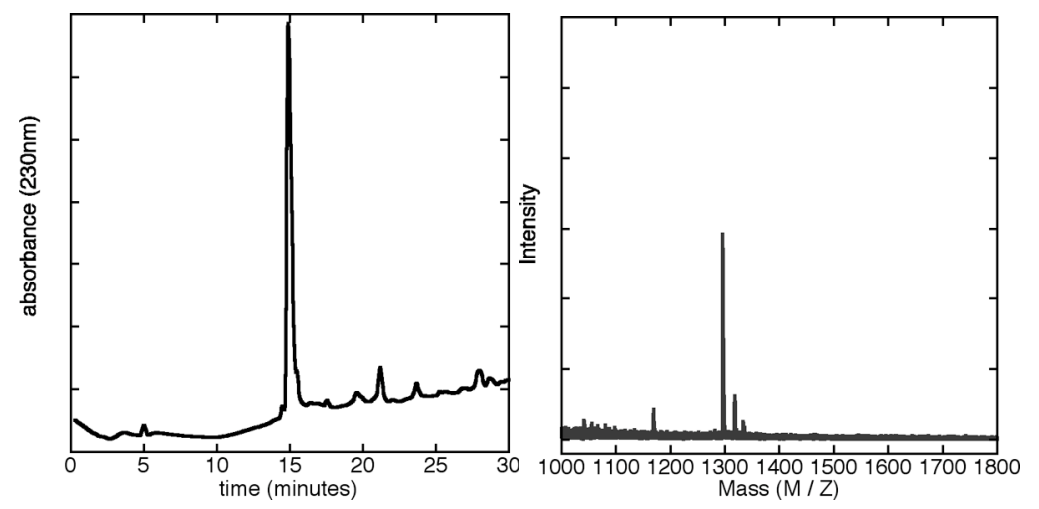

Supplemental Figure SI-9b. HPLC and MS of $\mathrm{K}_{2}(\mathrm{QL})_{3} \mathrm{~K}_{2}$. See SI10 for reinjection.
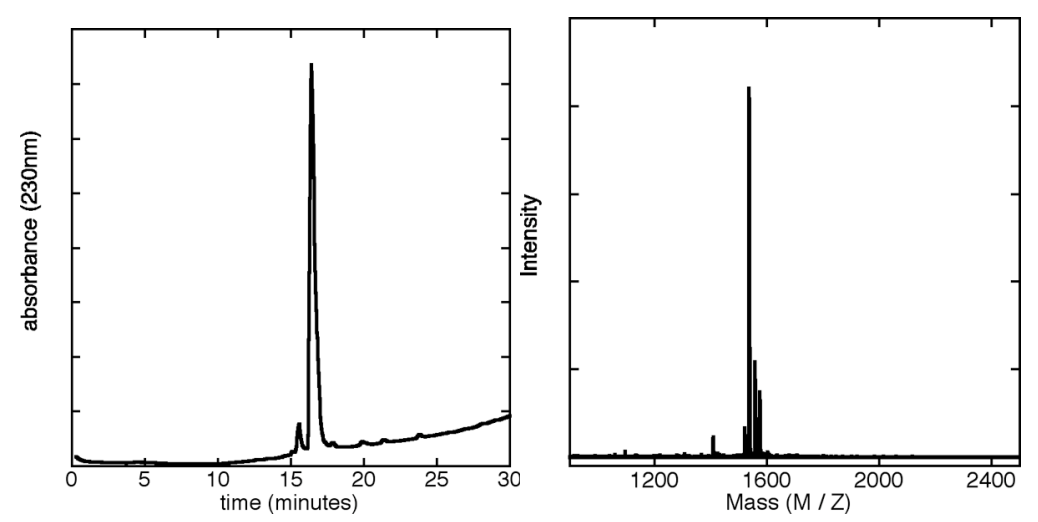

Supplemental Figure SI-9c. HPLC and MS of $\mathrm{K}_{2}(\mathrm{QL})_{4} \mathrm{~K}_{2}$ 

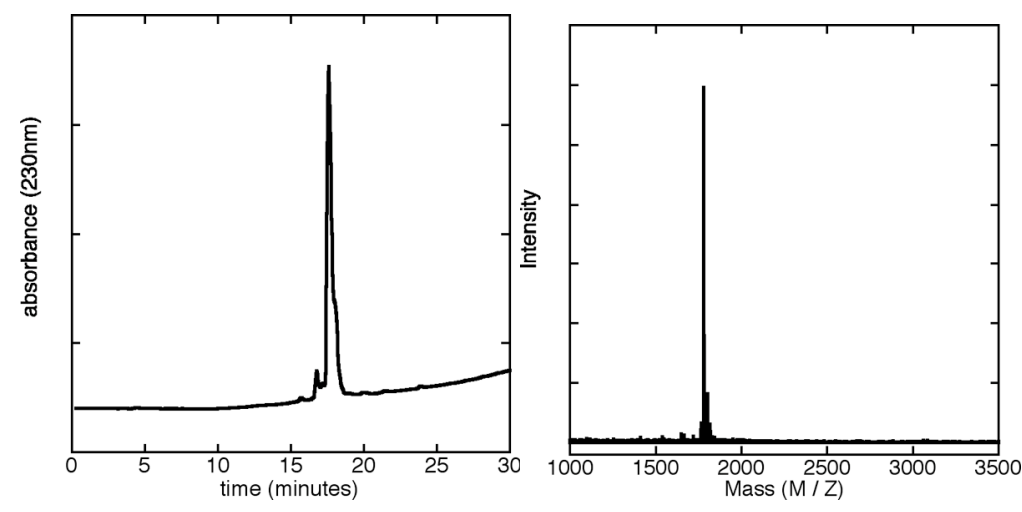

Supplemental Figure SI-9d. HPLC and MS of $\mathrm{K}_{2}(\mathrm{QL})_{5} \mathrm{~K}_{2}$
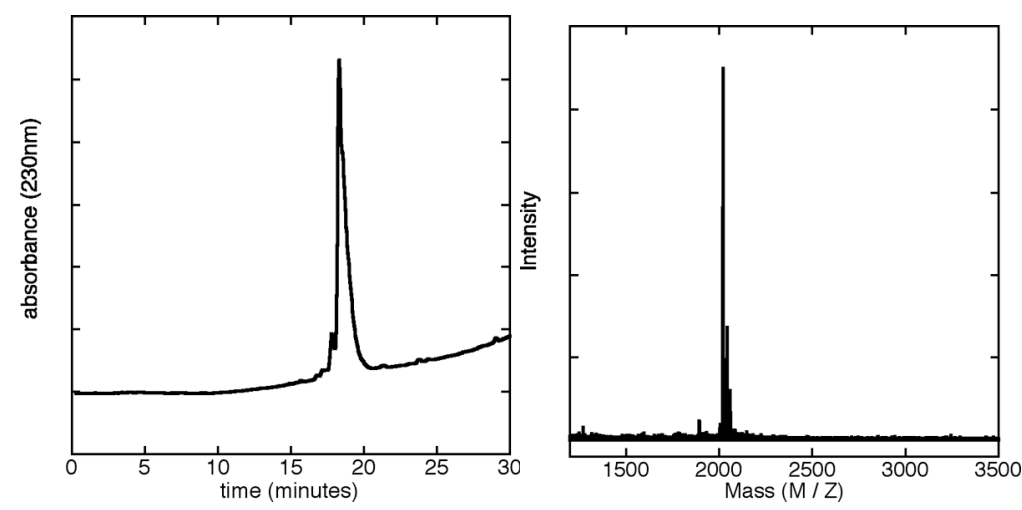

Supplemental Figure SI-9e. HPLC and MS of $\mathrm{K}_{2}(\mathrm{QL})_{6} \mathrm{~K}_{2}$
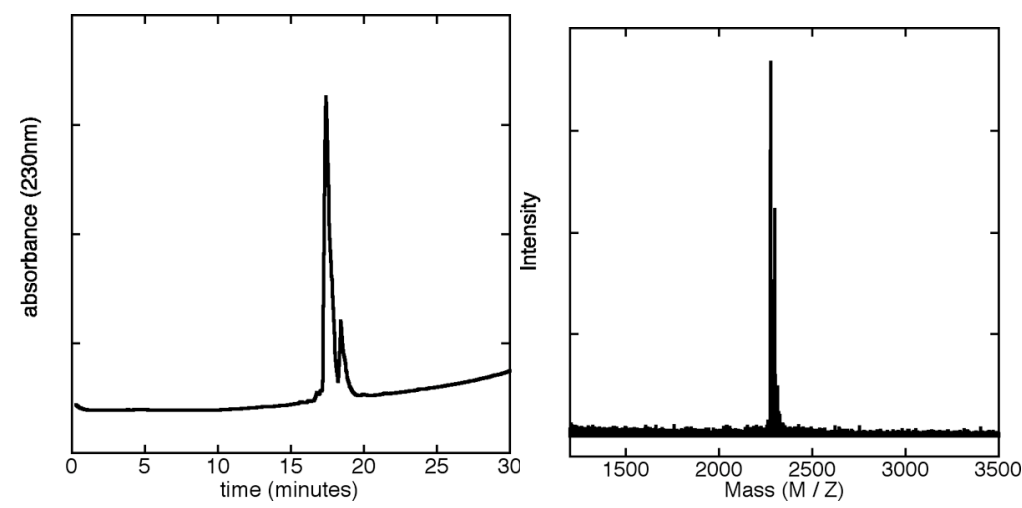

Supplemental Figure SI-9f. HPLC and MS of $\mathrm{K}_{3}(\mathrm{QL})_{6} \mathrm{~K}_{3}$ 

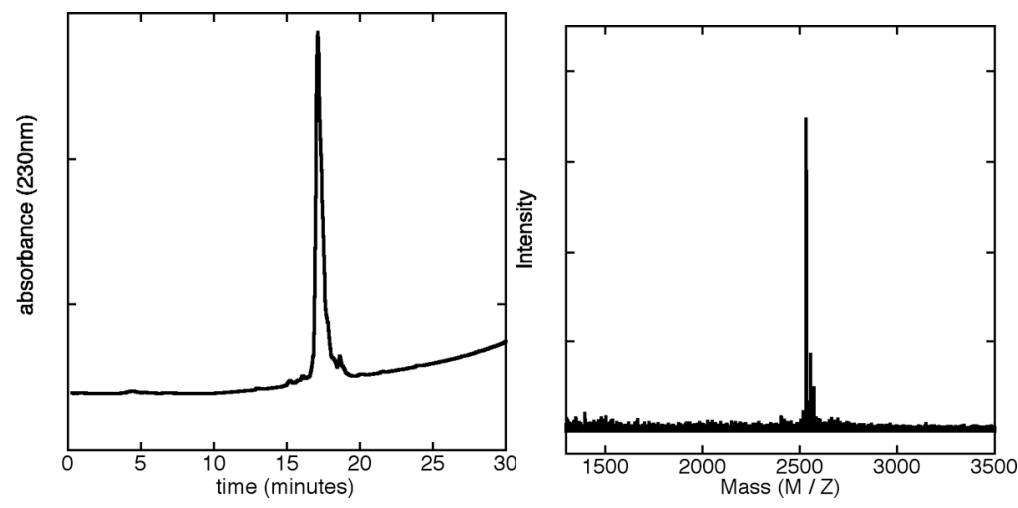

Supplemental Figure SI-9g. HPLC and MS of $\mathrm{K}_{4}(\mathrm{QL})_{6} \mathrm{~K}_{4}$

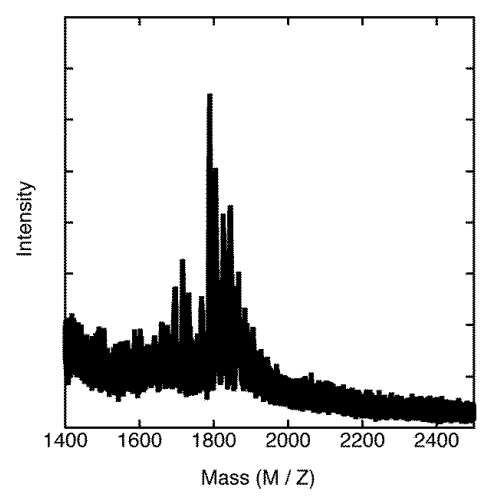

Supplemental Figure SI-9h. MS of K(QL) ${ }_{6} \mathrm{~K}$ 
(a)

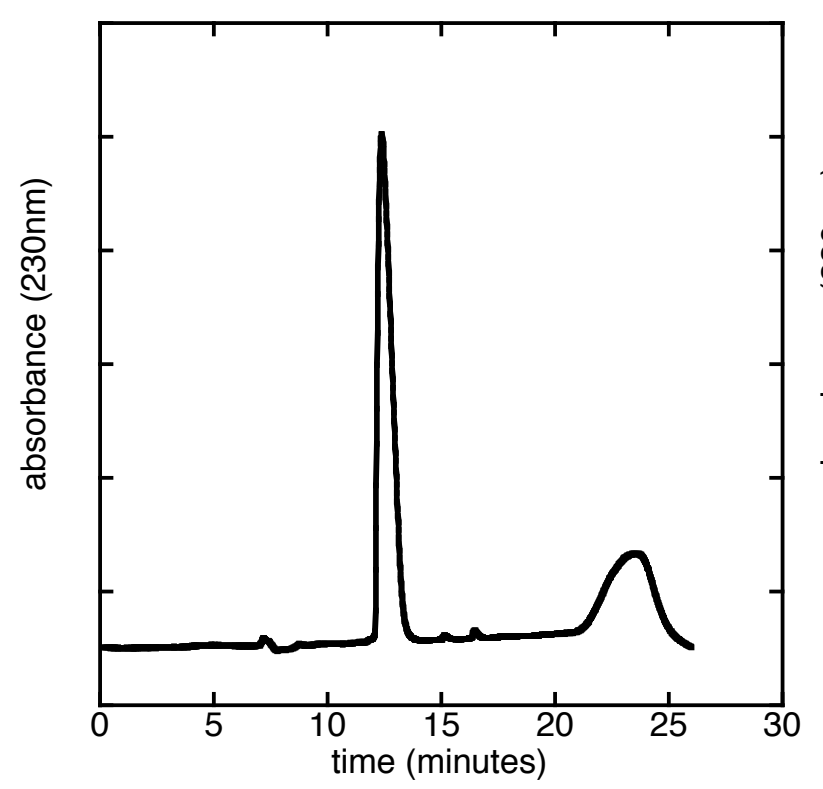

(b)

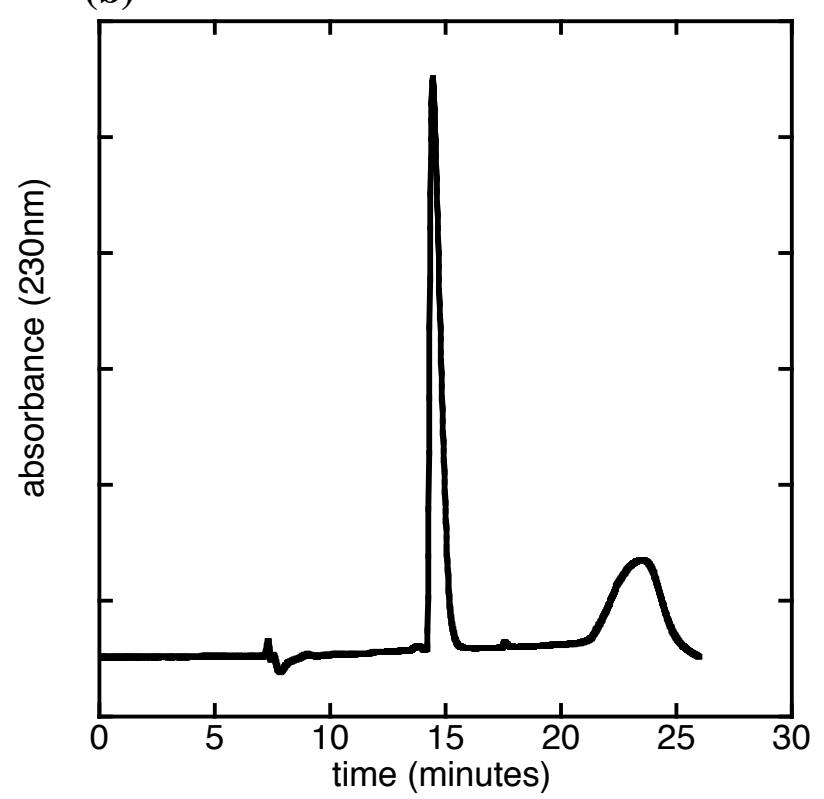

Supplementary Figure SI-10. (a) Reinjection of $\mathrm{K}_{2}(\mathrm{QL})_{2} \mathrm{~K}_{2}$ after purification. (b) Reinjection of $\mathrm{K}_{2}(\mathrm{QL})_{3} \mathrm{~K}_{2}$ after purification. 


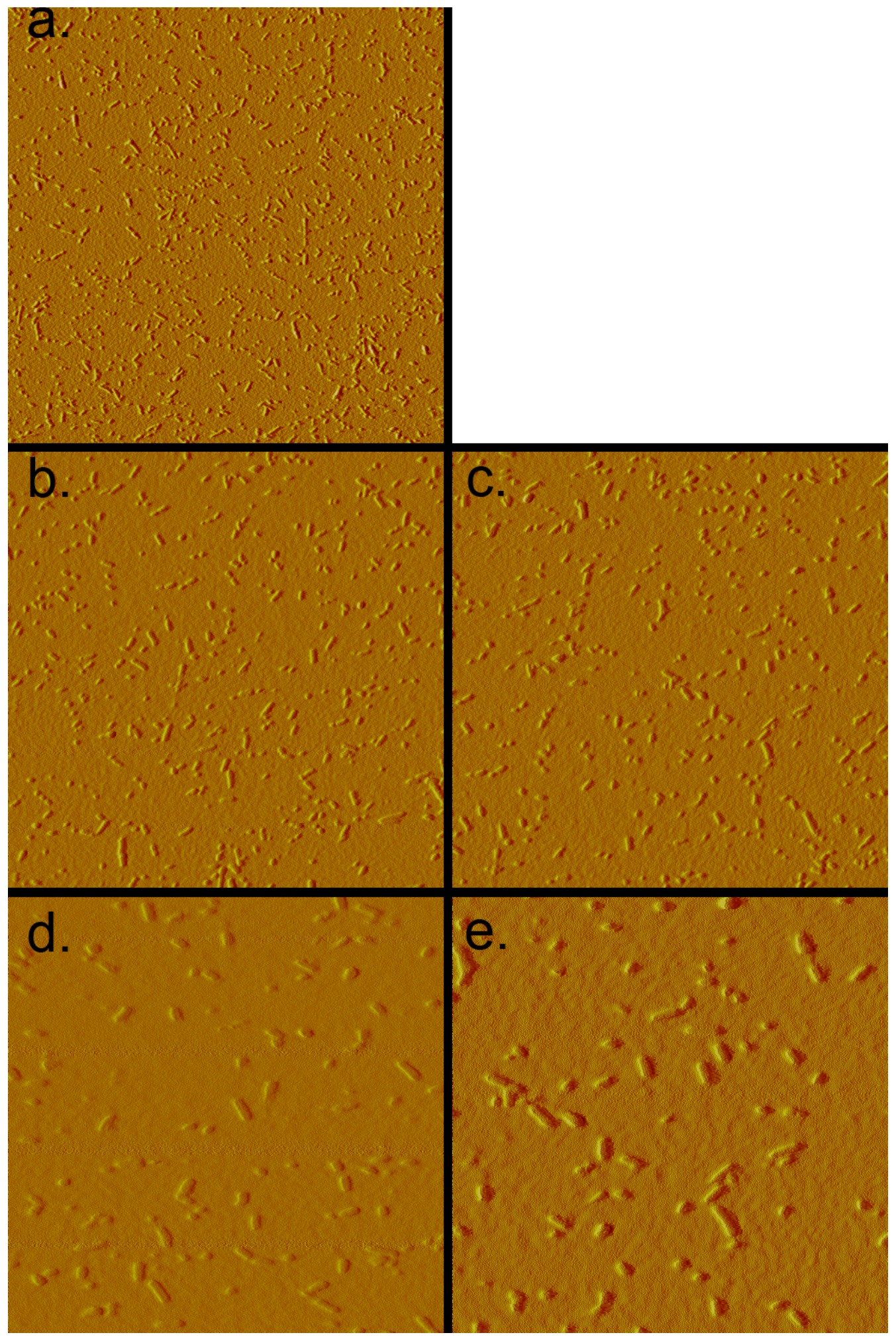

Supplementary Figure SI-11. Amplitude Tapping Mode AFM images of $\mathrm{K}_{2}(\mathrm{QL})_{6} \mathrm{~K}_{2}$ fibers deposited onto cleaved mica from a $0.01 \%$ by weight solution. $a$ ) image width $=3 \mu \mathrm{m} . b \& c$ ) image width $=2 \mu \mathrm{m} . \mathrm{d} \& \mathrm{e}$ ) image width $=1 \mu \mathrm{m}$. 


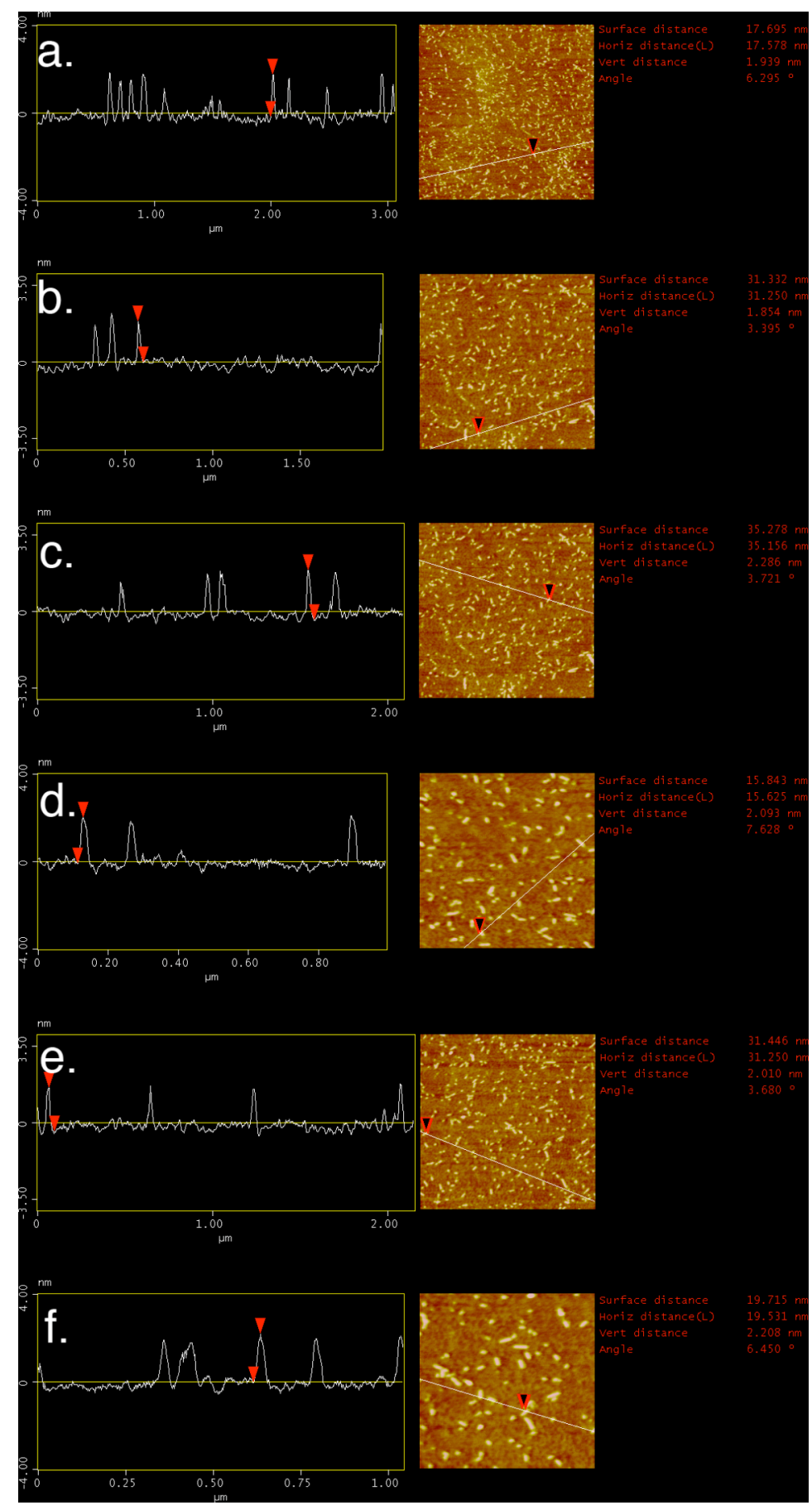

Supplementary Figure SI-12. Height analysis of $\mathrm{K}_{2}(\mathrm{QL})_{6} \mathrm{~K}_{2}$ fibers deposited onto cleaved mica from a $0.01 \%$ by weight solution. Fibers showed heights varying from $1.85 \mathrm{~nm}$ to $2.29 \mathrm{~nm}$ which is consistent with our model which predicts a height of $1.98 \mathrm{~nm}$.

Amplitude image in figure SI-11a corresponds to height image SI-12a. Amplitude image in figure SI-11b corresponds to height image SI-12b and c. Amplitude image in figure SI-11c corresponds to height image SI-12e. Amplitude image in figure SI-11d corresponds to height image SI-12d. Amplitude image in figure SI-11e corresponds to height image SI-12f. 

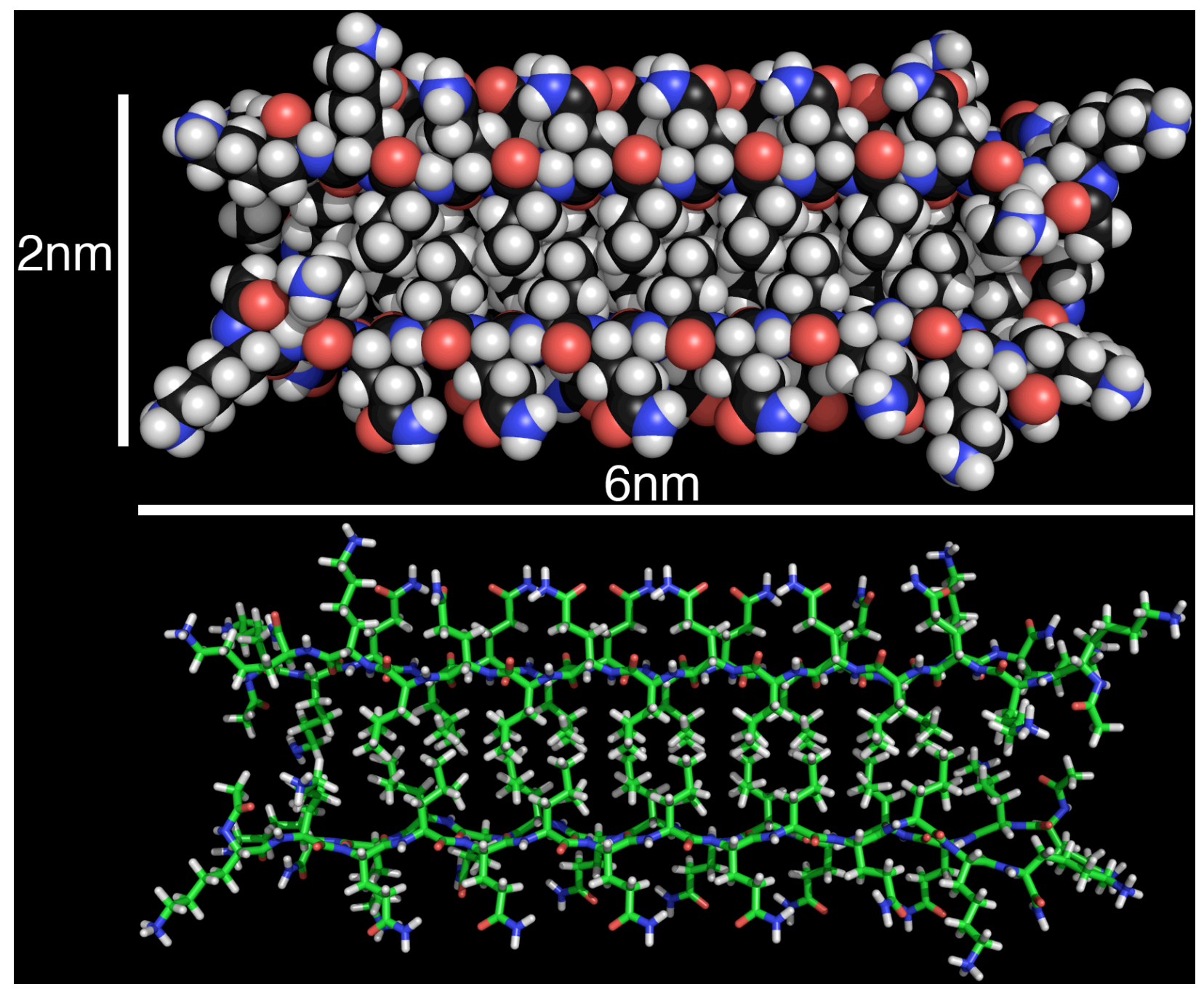

Supplementary Figure SI-13. Molecular models of K2(QL)6K2 in proposed packing conformation. View is down the hydrogen bonding axis with the hydrophobic core formed by leucine side chains in the center and hydrophilic faces formed by glutamine side chains. Left and right sides are flanked by positively charged lysine side chains. The top figure uses space filling spheres to represent atoms while the bottom figure uses sticks to represent bonds. Both models are of the same molecule and at the same scale. Approximate width can be seen to be $6 \mathrm{~nm}$ while depth is approximately $2 \mathrm{~nm}$. 